\title{
Collembola Poduromorpha (Entognatha) from continental Yemen and Socotra Island, with the description of a new Xenylla Tullberg, 1869
}

\author{
Wanda Maria WEINER \\ Institute of Systematics and Evolution of Animals, Polish Academy of Sciences, \\ Sławkowska 17, PL-31-016 Kraków (Poland) \\ weiner@isez.pan.krakow.pl \\ Judith NAJT \\ Muséum national d'Histoire naturelle, UMR 7205 du CNRS, \\ case postale 50, 57 rue Cuvier, F-75231 Paris cedex 05 (France) \\ Grzegorz PAŚNIK \\ Institute of Systematics and Evolution of Animals, Polish Academy of Sciences, \\ Sławkowska 17, PL-31-016 Kraków (Poland) \\ pasnik@isez.pan.krakow.pl
}

KEY WORDS Hypogastruridae, Brachystomellidae, Neanuridae,

Onychiuridae, new record, new species, new combination.

MOTS CLÉS Hypogastruridae, Brachystomellidae,

Neanuridae,

Onychiuridae, données nouvelles, espèce nouvelle, combinaison nouvelle.
Weiner W. M., Najt J. \& Paśnik G. 2012. - Collembola Poduromorpha (Entognatha) from continental Yemen and Socotra Island, with the description of a new Xenylla Tullberg, 1869. Zoosystema 34 (3): 553-560. http://dx.doi.org/10.5252/z2012n3a4

\section{ABSTRACT}

Collembola Poduromorpha Börner, 1913 belonging to the families of Hypogastruridae Börner, 1906, Brachystomellidae Stach, 1949, Neanuridae Börner, 1901 and Onychiuridae Lubbock, 1867 from Yemen were studied. A new species, Xenylla vanharteni $\mathrm{n}$. sp., is described with the combination of following characters: $5+5$ eyes present, mucro separated from dens and chaetotaxy of "bgklort" type. Remarks to the original description of Penelopella pohli (Barra, 2006) n. comb. is presented. New localities for seven further species are given.

\section{RÉSUMÉ}

Collembola Poduromorpha (Entognatha) du Yemen continental et de l'île Socotra, avec la description d'une nouvelle espèce de Xenylla Tullberg, 1869.

Les Collembola Poduromorpha Börner, 1913 des familles Hypogastruridae Börner, 1906, Brachystomellidae Stach, 1949, Neanuridae Börner, 1901 et Onychiuridae Lubbock, 1867 sont étudiés. Une espèce nouvelle, Xenylla vanharteni n. sp., est décrite. Elle presente la combinaison des caractères suivants : $5+5$ cornéules, mucron séparé de la dens et chaetotaxie du type "bgklort ". Un commentaire de la description de Penelopella pohli (Barra, 2006) n. comb. est présenté et de nouvelles localités sont données pour sept espèces. 


\section{INTRODUCTION}

The Collembola Lubbock, 1870 of Yemen have been till now almost unknown. Only four papers deal with this group: one of Bretfeld (2000) on Collembola Symphypleona Börner, 1901, three of Barra (2004a, b, 2006) on the genus Seira Lubbock, 1870 and on Collembola from Socotra Island. The present study is based on the material of Collembola Poduromorpha Börner, 1913 collected by Antonius Van Harten in the continental part of the country and from Socotra Island. The collected specimens belong to the following genera: Ceratophysella Börner, 1932, Xenylla Tullberg, 1869 (Hypogastruridae Börner, 1906), Brachystomella Ågren, 1903 (Brachystomellidae Stach, 1949), Penelopella Cassagnau, 1986 (Neanuridae Börner, 1901) and Thalassaphorura Bagnall, 1949 (Onychiuridae Lubbock, 1867).

\section{MATERIAL AND METHODS}

The material from continental Yemen and Socotra Island was collected by Antonius Van Harten during his employment in Department of Plant Protection, Sana’a (Yemen). Fourteen samples collected mainly in leaf litter or litter of conifers were handed over to study Collembola Poduromorpha. The geographic coordinates of the studied locality are available in Barra (2004a). Poduromorpha, found in twelve samples, were preserved in alcohol and in Marc André II on microscope slides.

\section{MORPHOLOGICAL TERMINOLOGY}

The terminology used in the text and Table 1 are derived from that of Deharveng (1983), Deharveng \& Weiner (1984), Smolis \& Deharveng (2006), Smolis (2008) and D'Haese (2003).

\section{ABBREVIATIONS}

\section{Body parts}

Abd. abdomen, abdominal;

Ant. I-IV antennal segments I-IV;

pl pleurite;

Scx1, Scx2 subcoxa 1, 2;

Th. thorax, thoracic.

Groups of chaetae
$\mathrm{Ag}$ antegenital;
$\mathrm{An}$ anal;
$\mathrm{Fu}$ furcal;
$\mathrm{Ve}$ ventroexternal;
$\mathrm{VL} \quad$ ventrolateral.
Tubercles
$\mathrm{Af}$ antenno-frontal;
$\mathrm{CL}$ clypeal;
$\mathrm{De}$ dorsoexternal;
$\mathrm{Di}$ dorsointernal;
$\mathrm{Dl}$ dorsolateral;
$\mathrm{L} \quad$ lateral;
$\mathrm{Oc}$ ocular;
$\mathrm{So}$ subocular.

Types of chaetae

$\begin{array}{ll}\text { ML } & \text { long macrochaeta; } \\ \text { me } & \text { mesochaeta; } \\ \text { mi } & \text { microchaeta; } \\ \text { ms } & \text { s-microchaeta (= microsensillum); } \\ \text { Oca, Ocm, Ocp } & \begin{array}{l}\text { ocular chaetae; } \\ \text { s }\end{array} \\ \text { S1-9 } & \text { sensory chaetae s; } \\ & \text { sensilla 1-9 on Ant. IV. }\end{array}$

Material deposit

HLDM Hessischen Landesmuseum, Darmstadt;

ISEA Institute of Systematics and Evolution of Animals, Polish Academy of Sciences, Kraków;

MNHN Muséum national d'Histoire naturelle, Paris.

\section{SYSTEMATICS}

Family HyPOGASTRURIDAE Börner, 1906

Genus Ceratophysella Börner, 1932

Ceratophysella denticulata (Bagnall, 1941)

Material eXamined. - Yemen, Madinat ash Shirq, 10.II.1993, in litter under coffee trees, A. Van Harten, 4 우 우 2 o $^{77}$ (ISEA Ye-93-1538). — Sana'a, 30.I.1999, in leaf litter, A. Van Harten, 1 ㅇ (ISEA Ye-99-3613); 30.V.1999, in litter of conifers, A. Van Harten, 3 우, 1 juv. (ISEA Ye-99-3687).

Geographical Distribution. - Cosmopolitan species.

Ceratophysella stercoraria Stach, 1963

Material eXamined. - Yemen, Sana'a, II.1991, A. Van Harten, 1 ㅇ (ISEA Ye-91-126); 1-10.VII.1999, in light 
trap, A. Van Harten, 1 \& 1 juv., 1 \%? (ISEA Ye-99-3828); 30.V.1999, in litter of conifers, A. Van Harten, 3 우 (ISEA Ye-99-3687).

Geographical distribution. - Described from Afghanistan, found in Eastern Europe, Bulgaria, Russia and Central Asia.

\section{Genus Xenylla Tullberg, 1869}

Xenylla welchi Folsom, 1916

Material eXAMined. - Yemen, Madinat ash Shirq, 3.V.2000, in leaf litter, A. Van Harten, 9 ९ , 1 ○ (ISEA Ye-00-4520).

Geographical Distribution. - Cosmopolitan species.

Xenylla yucatana Mills, 1938

Material eXamined. - Yemen, Khamis Bani Sa'd, 9.VI.99, in leaf litter, A. Van Harten, 6 우, $50^{7} 0^{7}$ (ISEA Ye-99-3747); in leaf litter in banana plantation, 23.VI.99, A. Van Harten, 6 우, 1 ơ, 1 juv. (ISEA Ye-99-3761).

GeOgraphiCAL DisTRIBUTION. — Known from Neotropi$\mathrm{cal}$, Afrotropical, Oriental and Australian regions.

\section{Xenylla vanharteni $\mathrm{n}$. sp.} (Fig. 1)

TYPe MATERIAL. - Holotype: Yemen, Khamis Bani Sa'd, in leaf litter in banana plantation, 23.VI.1999, A. Van Harten, 9 (ISEA Ye-99-3761/1).

Paratypes: same data as holotype, 2 On $^{7}$ (ISEA Ye-993761/5-6), 2 우 (ISEA Ye-99-3761/2-3), 1 ㅇ (MNHN Ye-99-3761/4); same data as holotype, but 31.VIII.1999, 1 ㅇ (ISEA Ye-99-4019).

TyPe LOCAlity. - Yemen, Khamis Bani Sa'd.

ETYMOLOGY. - This species is cordially dedicated to Antonius Van Harten who kindly collected the studied material.

Diagnosis. - Habitus typical for the genus Xenylla with $5+5$ eyes, chaetotaxy of "bgklort" type, dens with two chaetea, mucro separated from dens.

\section{DESCRIPTION}

Length: holotype $0.85 \mathrm{~mm}$, paratype females $0.94-$ $1.06 \mathrm{~mm}$, paratype males $0.86-0.9 \mathrm{~mm}$. Colour: spotted blue, Oc plate dark. Tegumental granulation rather fine.

Antennae as long as head. Ant. I with seven chaetae, Ant. II with 11 chaetae. Sensory organ of antennal segment III consisting of two subcylindrical internal sensilla, two small subcylindrical guard sensilla and ventral ms. Ant. IV with three short subcylindrical sensilla (S7, S8, S9) externo-lateral and one shorter dorsal sensilla (S2), two interno-ventral sensilla (S1 \& S3) longer and thiner, small ms placed among two latero-external sensilla, small subapical organite and bilobed apical vesicle (Fig. 1B).

$5+5$ eyes present, postantennal organ absent. Buccal cone typical for the genus. Chaetotaxy of labrum: 4/4554.

Chaetotaxy type as "bgklort" (according to Gama 1988), dorsal chaetotaxy as in Figure 1A, with rather short, ordinary chaetae, with thin and long sensory chaetae $s$, their formula per half tergum: $022 / 11111$. Head with chaeta a0 present, chaeta c1 absent (character b after Gama 1988; Thibaud et al. 2004). Serrated chaeta 13 longer than chaeta 11 (character g). Chaetae $\mathrm{m} 3$ and $\mathrm{p} 3$ on Th. terga IIIII absent (characters $\mathrm{k}$ and $\mathrm{l}$ ). Abd. tergum IV without chaetae m3 (character o) and with p3 (p3 and $\mathrm{p} 4$ displaced forwards than $\mathrm{p} 2$ and $\mathrm{p} 5=\mathrm{s}$ ). Very small An spines present on Abd. tergum VI. Ventral side of head without chaeta p1 (character r), with chaeta $\mathrm{m} 3$. Th. sterna without chaetae (character $\mathrm{t}$ ). Ventral chaetotaxy as in Figure 1E: chaetae p1 and p6 present, chaeta $\mathrm{p} 2$ absent on Abd. sternum II, chaetae $\mathrm{a} 6$ and $\mathrm{p} 5$ present on Abd. sternum III, Abd. sternum IV with chaeta $\mathrm{m} 1$. Ventral tube with $4+4$ chaetae.

Tibiotarsi I, II and III with 19, 19 and 18 chaetae respectively, with capitated chaetae A1 on tibiotarsi IIII and A7 on II-III, with chaetae M and without chaeta B7 on tibiotarsus III. Femora I, II and III with 12, 11 and 10 chaetae respectively, trochanters with 5,5 and 4 chaetae respectively, coxae I, II and III with 3, 7 and 7 chaetae, Scx 2 I, II and III with 0,2 and 2 chaetae, Scx 1 I, II and III with 1 , 2 and 3 chaetae respectively. Claws with subapical tooth (Fig. 1C).

Furca present, mucro with hook at the top and well-developed lamella separated from dens with two chaetae. Ratio mucro : dens = $1: 1.5$ (Fig. 1D, E). 


\section{REMARKS}

Among the species of Xenylla with $5+5$ eyes, mucro separated from dens with two chaetae each and chaeta $\mathrm{cl}$ absent on the head (character b, after Thibaud et al. 2004), the new species is most similar to Xenylla kenyensis (chaetotaxy type "bklnorst") described by Gama (1983) from Kenya. Both species share the following characters (the characters for X. kenyensis after Gama 1983): chaetae a1 and a2, p1 and p2 on Th. terga II and III not deplaced, disposed on the same level, chaeta $\mathrm{m} 3$ on the Th. terga II and III absent (character $\mathrm{k}$ ), chaeta $\mathrm{p} 3$ on Th. terga II and III absent (character 1), chaeta $\mathrm{m} 3$ on Abd. tergum IV absent (character o). On the ventral side of the body they have neither chaeta $\mathrm{p} 1$ on the head (character $r$ ), nor a pair of chaetae on Th. sterna II-III (character $\mathrm{t}$ ). Both species differ in the shape of mucro (more hooked in the new species), by chaeta 13 lenght (longer than 11 [character g] in the new species and $11=13$ in $X$. kenyensis), by the presence of chaeta $\mathrm{p} 3$ in the new species (absent in $X$. kenyensis [character $\mathrm{n}$ ]), by the chaeta $\mathrm{m} 3$ present on the ventral side of the head in the new species and absent in $X$. kenyensis (character s). The Ant. IV with six sensilla in the new species and by the number of sensilla on Ant. IV (six in the new species, only four in $X$. kenyensis).

The new species is also very similar to Xenylla lesnei described by Denis (1935) from Mozambique. However, chaetotaxy of the head and body is lacking in the description and the type material seems to be lost. Dens and mucro have been presented for two specimens (A \& B, Denis 1935: figs 3, $6)$ and probably belong to different species. The following characters are similar in $X$. lesnei and in the new species: the number of sensilla on Ant. IV segment, the type of dens and mucro, the number of capitated chaetae on tibiotarsi. Both species differ by the size of mucro $(71 \%$ of dens in the new species and $63-67 \%$ in $X$. lesnei) by the shape of mucro-dens (more slender, especially in specimen A of $X$. lesnei), by the ratio of claw : mucro $=1$ : 1.15-0.95 (for specimens A \& B of X. lesnei) and $1: 0.89$ in $X$. vanharteni $n$. sp. The interno-ventral sensilla (S1 and S3) in Ant. IV segment are longer and stouter in the new species.

\author{
Family BRACHYSTOMELLIDAE Stach, 1949 \\ Genus Brachystomella Ågren, 1903
}

\section{Brachystomella contorta Denis, 1931}

Material examined. - Yemen, Khamis Bani Sa'd, 23.VI.1999, in leaf litter in banana plantation, A. Van Harten, 2 우 (ISEA Ye-99-3761); 31.VIII.1999, in leaf litter in banana plantation, A. Van Harten, 1 (ISEA Ye-99-4019). - Yemen, Madinat ash Shirq, 03.V.2000, in leaf litter, A. Van Harten, 11 \&, 1 ơ, 2 juv., 1 indet. (ISEA Ye-00-4520).

Geographical distribution. - Known from Central and South America, Africa, Malaya, India.

\section{Brachystomella platensis Najt \& Massoud, 1974}

Material eXamined. - Yemen, Sana’a, 27.XII.1998, in leaf litter in a garden, A. Van Harten, $26 \% \%, 30^{7} 0^{\prime \prime}$, 4 juv., 1 indet. (ISEA Ye-98-3522).

Geographical distribution. - Till now this species is known from Argentina, Australia and Tasmania.

\section{Brachystomella surendrai Goto, 1961}

Material eXamined. - Yemen, Ta'izz, 10.VIII.1999, in litter of Nerium oleander, A. Van Harten, $8 \% \circ, 40^{\prime \prime} 0^{\prime \prime}$, 5 juv. (ISEA Ye-99-3888).

GEOgRAPHiCAL Distribution. — Till now known only from India.

Family NEANURIDAE Börner, 1901

Subfamily NEANURINAE Börner, 1901

Tribe PALEOnURINi Cassagnau, 1989

Genus Penelopella Cassagnau, 1986

Penelopella pohli (Barra, 2006) n. comb. (Fig. 2; Table 1)

Neanura (Neanura) pohli Barra, 2006: 63-65, fig.1.

Material examined. - Holotype: Socotra, Wadi Daneghan, 21-22.X.2000, HP, ơ (HLDM-Apt-33-HT). Paratype: Di-Fa'rohr, 25.X.2000, HP, 1 \% (HLMDNHCY-PT1). 

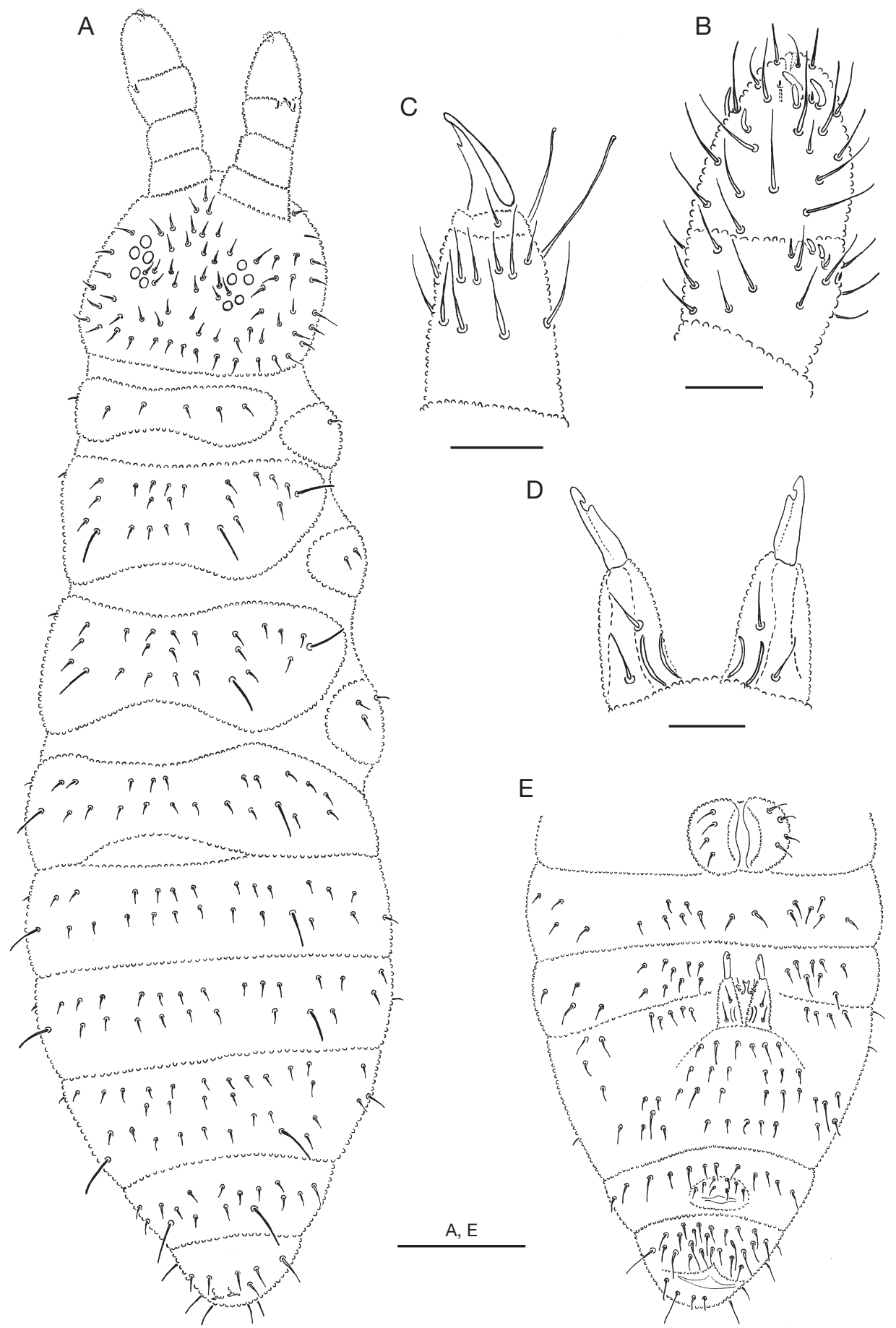

FIG. 1. - Xenylla vanharteni n. sp.: A, dorsal chaetotaxy; B, antennal segments III and IV, dorso-lateral view; C, tibiotarsus III; D, dens with mucro; E, ventral chaetotaxy of abdomen. Scale bars: A, E, $0.1 \mathrm{~mm}$; B-D, $0.01 \mathrm{~mm}$. 
TABle 1. - Chaetotaxy of Penelopella pohli (Barra, 2006). Abbreviation: *, with some asymmetry; others abbreviations, see Material and methods.

\begin{tabular}{|c|c|c|c|c|}
\hline \multicolumn{5}{|c|}{ Cephalic chaetotaxy } \\
\hline $\begin{array}{l}\text { Group of } \\
\text { chaetae }\end{array}$ & Tubercle & $\begin{array}{l}\text { Number of } \\
\text { chaetae }\end{array}$ & $\begin{array}{l}\text { Type of } \\
\text { chaetae }\end{array}$ & Chaetae \\
\hline$\overline{\mathrm{Cl}+\mathrm{Af}}$ & + & 10 & $\begin{array}{l}\mathrm{ML} \\
\mathrm{me}\end{array}$ & $\begin{array}{c}B, F \\
C, D, G\end{array}$ \\
\hline Oc & + & 3 & $\begin{array}{c}\mathrm{ML} \\
\mathrm{mi}\end{array}$ & $\begin{array}{c}\text { Ocp, Ocm } \\
\text { Oca }\end{array}$ \\
\hline $\mathrm{Di}, \mathrm{De}$ & + & 4 & $\begin{array}{c}\mathrm{ML} \\
\mathrm{me} \\
\mathrm{mi}\end{array}$ & $\begin{array}{c}\text { De2 } \\
\text { Di1 } \\
\text { Di2, De2 }\end{array}$ \\
\hline DI & + & 4 & $\begin{array}{l}\mathrm{ML} \\
\mathrm{me} \\
\mathrm{mi}\end{array}$ & $\begin{array}{l}\text { DI 1, DI } 5 \\
\text { DI } 4 \\
\text { DI } 2\end{array}$ \\
\hline$L+$ So & + & 8 & $\begin{array}{c}\mathrm{ML} \\
\mathrm{me} \\
\mathrm{mi}\end{array}$ & $\begin{array}{c}\mathrm{L} 1 \text {, So } 1 \text {, So } 4 \\
\mathrm{~L} 2, \mathrm{~L} 3, \mathrm{~L} 5-6 \\
\mathrm{~L} 4\end{array}$ \\
\hline
\end{tabular}

Postcephalic chaetotaxy per half tergum

\begin{tabular}{|c|c|c|c|c|}
\hline & Di & $\mathrm{De}$ & DI & $L=\operatorname{Scx} 1 / p l$ \\
\hline Th. I & 1 & 2 & - & 1 \\
\hline Th. II & 3 & $2+s$ & $3+s+m s$ & 3 \\
\hline Th. III & 3 & $2+s$ & $3+s$ & 3 \\
\hline Abd. I & 2 & $2+s$ & 2 & $3+s$ \\
\hline Abd. II & 2 & $2+s$ & 2 & $3+s$ \\
\hline Abd. III & 2 & $2+s$ & 2 & $2+s$ \\
\hline Abd. IV & 2 & $1+s$ & 3 & 6 \\
\hline Abd. V & 2 & \multicolumn{2}{|c|}{$6-7^{*}+s$} & \\
\hline Abd. VI & - & & & \\
\hline
\end{tabular}

Chaetotaxy of abdominal sterna

\begin{tabular}{lcccc}
\hline Abd. sterna & Ve & Ag/An & Fu & VL \\
\hline II & $4^{*}$ & - & - & - \\
III & $4^{*}$ & - & $3+3^{*}$ & 1 \\
IV & 7 & - & - & 4 \\
V & - & 5 & - & 1 \\
VI & 13 & $2 \mathrm{mi}$ & - & - \\
\hline
\end{tabular}

OTHER MATERIAL. - Socotra, Wadi Daneghan, natural landscape, steep valley with a permanent stream, with rather dense vegetation on the valley sides, leaf litter under a Ficus tree, 30.X.2000, A. Van Harten, 1 o", 2 우 (ISEA Ye-00-4905/1-3).

\section{REDESCRIPTION}

Colour in life orange (A. Van Harten, pers. com.), white in alcohol, eyes without pigmentation. Tubercles not developed in medial part of Th. terga I-III and Abd. terga I-IV. Abd. VI bilobated (Fig. 2A, H).

Ant. I with seven chaetae, Ant. II with 11 chaetae. Ant. III and IV fused dorsally, ventral separation well marked. Sensory organ of antennal segment III consisting of: two small internal sensilla bent in the same direction, two subcylindrical guard sensilla (ventral one longer than the dorsal one), ventral ms present. Antennal segment IV with ordinary chaetae, dorsally with eight distinct, subcylindrical sensilla: seven DL and one lateral, without ms, with subapical organite and trilobated apical vesicle (Fig. 2B, C). Mandible with two teeth, maxilla unlamellated with small hook at apex (Fig. 2G). Labrum long with $0 / 22$ chaetae (Fig. 2D, E). Labium without chaeta B (Fig. 2F).

Dorsal chaetotaxy as in Figure 2A and Table 1. All ordinary chaetae covered with a weak sheath and slightly serrated. Sensory chaetae s rather long, their formula per half tergum: 022/22221. Th. sterna without chaetae. Abd. chaetotaxy in Figure $2 \mathrm{H}$ and Table 1.

Tibiotarsi I, II and III with 18, 18 and 17 chaetae respectively, with acuminate distal chaetae. Chaeta $\mathrm{M}$ absent. Femora I, II and III with 13, 12 and 11 chaetae, respectively, trochanters with 6 chaetae each, coxae I, II and III with 3, 7 and 8 chaetae, Scx 2 I, II and III with 0, 2 and 2 chaetae, respectively, Scx1 (= tubercle L) I, II and III with 1,3 and 3 chaetae.

\section{REMARKS}

The material collected by Antonious Van Harten and the observation of holotype and paratype (now very transparent) allowed us to transfer Neanura pohli to the genus Penelopella. The genus was created by Cassagnau (1986) for the species described from Fiji and Vanuatu (Efate) islands and till now not found elsewhere. The genus Penelopella can be characterised by the following combination of characters: one additional sensory chaeta $s$ in lateral tubercle (L) of Abd. segments I-III, tubercles Di not developed on head, Th. and Abd. segments I-IV, $2+2$ eyes without pigment, absence of blue pigment of the body, central chaetotaxy of the head (tubercle Cl-Af) without chaetae $\mathrm{O}, \mathrm{A}$ and $\mathrm{E}$.

Pelenopella pohli differs from P. pacyfica Cassagnau, 1986 in the much better differentiated tubercles not only on three last Abd. segments, but also on the head, Th. I-III and Abd. terga I-III. The species from Socotra Island possess also two normal chaetae and one chaeta s on external tubercles (De) of Abd. segments I-IV while in P. pacyfica it has only one normal chaeta and one chaeta s. 


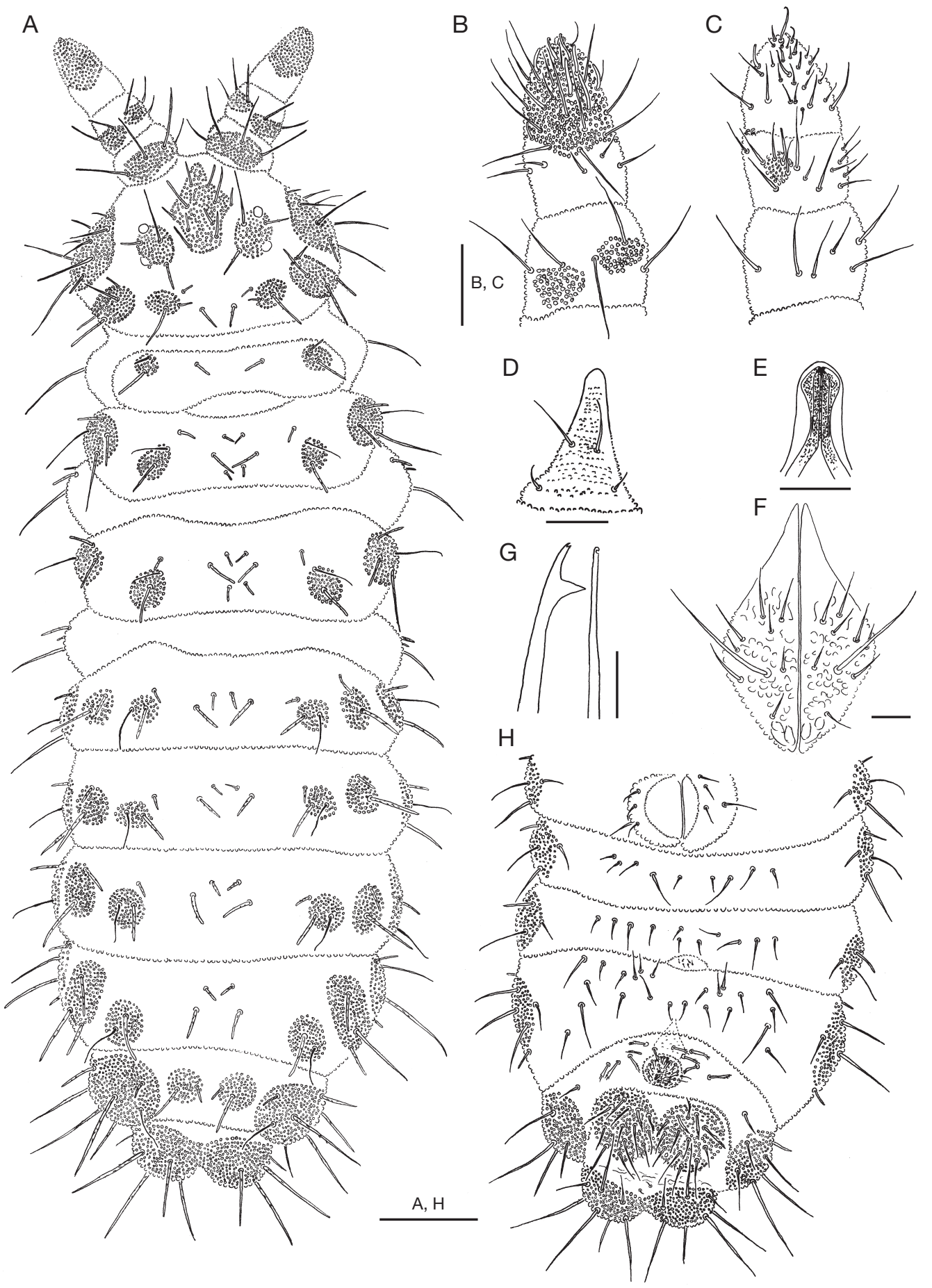

FIG. 2. - Penelopella pohli (Barra, 2006) n. comb.: A, dorsal chaetotaxy; B, antennal segments III and IV, dorsal view; C, antennal segments III and IV, ventral view; D, labrum; E, apex of labrum, ventral view; F, labium; G, mandible and maxilla; H, ventral chaetotaxy of abdomen. Scale bars: A, H, $0.1 \mathrm{~mm}$; B-G, $0.01 \mathrm{~mm}$. 
Family ONYCHIURIDAE Lubbock, 1867

Subfamily ONYCHIURINAE Börner, 1901

Tribe Thalassaphorurini Pomorski, 1998

Genus Thalassaphorura Bagnall, 1949

\section{Thalassaphorura encarpata (Denis, 1931)}

Material examined. - Yemen, Madinat ash Shirq, 3.V.2000, in leaf litter, A. Van Harten, 6 ㅇ (ISEA Ye-00-4520).

Geographical Distribution. - Cosmopolitan species in anthropogenic.

\section{DISCUSSION}

The study allowed us to present Collembola Poduromorpha from continental part of Yemen (nine species) and from Socotra Island (one species). From all species collected by A. Van Harten only two were known so far from Socotra (Barra 2006) and eight were mentioned for the first time in Yemen. The species are cosmopolitan species or are known from Oriental, Afrotropical, Neotropical and Australian regions. The paucity of genera (five) and species (10) may result from the small number of available samples (in total 14), mostly from leaf litter, and not from deeper soil layers, which probably could be more representative in this climate.

\section{Acknowledgements}

We are most grateful to Antonius Van Harten who has made the materials described here available to us. We are greatly indebted to the staff of Hessisches Landesmusem in Darmstadt (Germany): Ina Bush, Ursula Bummel, Birgit Meyer and Jörg Köhler who lent us the type material of Penelopella pohli. We would also like to thank Laszlo Dany, Annemarie Ohler and the anonymous reviewer for their valuable remarks which helped us to prepare the final version of our paper.

\section{REFERENCES}

BARRA J.-A. 2004a. - Le genre Seira (Collembola, Entomobryidae) du Yémen continental. Zoosystema 26 (2): 291-306.

BARRA J.-A. 2004b. - Springtails of the genus Seira Lubbock, 1869 (Collembola: Entomobryidae) from Socotra Island. Fauna of Arabia 20: 399-408.

BARRA J.-A. 2006. - Collemboles de l'île de Socotra, République du Yémen. Zoosystema 28 (1): 61-74.

BRETFELD G. 2000. — Collembola Symphypleona (Insecta) from the Republic of Yemen. Abhandlungen und Berichte des Naturkundemuseums Görlitz 72 (2): 153-176.

CASSAgnau P. 1986. - Sur l'évolution des Neanurinae paucitubercules à pieces buccales réduites, in DALLAI R. (ed.), 2nd International Seminar on Apterygota. University of Siena, Siena: 313-317.

D'HAese C. A. 2003. - Homology and morphology in Poduromorpha (Hexapoda, Collembola). European Journal of Entomology 101: 385-407.

DeHARVEng L. 1983. - Morphologie évolutive des Collemboles Neanurinae en particulier de la lignée néanurienne. Travaux du Laboratoire d'Ecobiologie des arthropodes édaphiques, Toulouse 4 (2): 1-63.

Deharveng L. \& WeINer W. M. 1984. — Collemboles de Corée du Nord. III - Morulinae et Neanurinae. Travaux du Laboratoire d'Ecobiologie des arthropodes édaphiques, Toulouse 4 (4): 1-61.

DENIS J. R. 1935. - Contributions à l'étude de la faune du Mozambique. Voyage de M. P. Lesne. Memórias e Estudos do Museum Zoológico da Universidade de Coimbra 86: 3-8.

GaMA M. M. DA 1983. — Systématique évolutive des Xenylla. XIII. Espèces provenant du Kenya (Insecta: Collembola). Revista da Universidade de Coimbra 29: 249-257.

GaMA M. M. DA 1988. — Filogenia des espécies Xenylla à escala mundial (Insecta, Collembola). Evolución Biológica, Coimbra 2: 139-147.

SmOLIS A. 2008. - Review of the Polish Deutonura Cassagnau, 1979 (Collembola: Neanuridae: Neanurinae) with redescription of D. conjuncta (Stach, 1926). Acta Zoologica Cracoviensia 51B (1-2): 43-82.

Smolis A. \& Deharveng L. 2006. — A new species of Pronura Delamare Deboutteville, 1953 from North Vietnam (Collembola: Neanuridae: Neanurinae). Annales Zoologici 56 (3): 443-448.

Thibaud J.-M., Schulz H.-J. \& Gama M. M. DA 2004. - Synopses on Palaearctic Collembola. Part IV. Hypogastruridae. Abhandlungen und Berichte des Naturkundemuseums Görlitz 75 (2): 1-287. 